\title{
Biotechnological approaches of watermelon to meet the future challenges for next decades
}

\author{
Rubaiyat Sharmin Sultana ${ }^{1, ~ *, ~ M d . ~ M a h a b u b u r ~ R a h m a n ~}{ }^{2}$ \\ ${ }^{1}$ Department of Botany, University of Rajshahi, Rajshahi 6205, Bangladesh \\ ${ }^{2}$ Research Institute for Sustainable Humanosphere, Kyoto University, Uji, Kyoto 611-0011, Japan (Present address)
}

\section{Email address:}

sultanaru@yahoo.com(R. S. Sultana)

\section{To cite this article:}

Rubaiyat Sharmin Sultana, Md. Mahabubur Rahman. Biotechnological Approaches of Watermelon to Meet the Future Challenges for Next Decades. Advances in Bioscience and Bioengineering. Vol. 1, No. 2, 2013, pp. 40-48. doi: 10.11648/j.abb.20130102.11

\begin{abstract}
Watermelon [Citrullus lanatus (Thunb.) Matsum. \& Nakai] is widely produced and consumed around the world as fleshy fruits. According to consumer and grower preferences, and market conditions (i.e. seedless varieties, good shelf life, etc.), many different cultivars are grown. The largest producer of watermelon in the world is China, is accounted for over $50 \%$ production by weight. Increasing in the production of melons is required for a growing population over the next decades. The production of total watermelons approximately doubled in 2009 from 2005 and currently it stabled. For consequences of climate alterations, declining agricultural land and water resources, and assailing microbes and pests, the demands of watermelon fruits are worsen. The watermelons production can be reached at an efficient level with cultivation of elite varieties such as, drought tolerance, disease resistant, high yield, which will be pivotal to success. It is important to improve of watermelon with the traits such as, seedless, good shelf life, excellent flesh color and good shapes that will make them more attractive to consumers. In order to generate elite varieties in watermelon, plant breeding with respect to conventional or molecular breeding methods must be reoriented to meet the global demand for next decades. Reports in here reveal some advanced work related to biotechnology that pivotal for enhancement of watermelon production.
\end{abstract}

Keywords: Biotechnology, Elite Variety, Genetic Information, Genetic Transformation, Micropropagation, Watermelon, Molecular Breeding

\section{Introduction}

In the human diet, Citrullus lanatus (Thunb.) Matsum. \& Nakai is widely consumed as fruit, is commonly known as watermelon, belongs to the family Curcubitaceae. The watermelon differs in producing berries with a harder rind when compared with the other melons. There are more than 1,200 varieties of watermelon grown in many regions of the world, which are varied with shape and color [1]. There are a large number of commercial cultivars in the United States, Japan and elsewhere such as, Dixic Queen, Big Top, Sweet Marvel, etc. Moreover, different cultivars of watermelon had been crossbred to improve suitability for commercial production (e.g. robustness for transport, disease resistance) and consumer appeal (e.g. seedless and sweeter cultivars). According to FAOSTAT [2], out of 609 million tons total fruits production in the year 2009, melons production was estimated $20 \%$ while majority was watermelon. The production of watermelon is stabled; therefore, it is required to increase in the production of watermelon for a growing population over the next decades.

Fruits and vegetables come in a rainbow of colors. To consume everyday a variety of colorful fruits and vegetables (red, yellow/orange, white, green and blue/purple) is good for health. These may lower the risk of some cancers. Watermelon is found in the red and yellow/orange color groups. Red color group watermelon helps maintain heart health, memory function and urinary tract health; yellow/orange color group watermelon helps maintain heart health, vision health and healthy immune system. Most melons are similar in their calorie and carbohydrate content, but the vitamin and mineral contents vary between each type of melon. Watermelon is lower in vitamins and minerals than most other melons, but contains antioxidants that provide its red color. One cup of raw, diced watermelon contains 46 calories, nearly all of which come from $11.5 \mathrm{~g}$ of carbohydrates, and contains less than $1 \mathrm{~g}$ of protein and fat. Although many fruits are high in fiber, watermelon is not. One cup contains only $0.6 \mathrm{~g}$, which is less than $5 \%$ of the recommended dietary allowance (RDA), 
of fiber for most adults. It also supplies less than $10 \%$ of the RDA of all vitamins and minerals except vitamin $\mathrm{C}$. One cup provides $16 \%$ of the RDA of vitamin $C$ for women, and $14 \%$ for men. Watermelon also contains lycopene, an antioxidant that may help prevent cell damage and boost the immune system.

Since industrial revolution, global climate has changed for releasing the major greenhouse gases, especially $\mathrm{CO}_{2}$. Since the last century tropospheric ozone has increased 2to 5- folds. As statements of United Nation's Intergovernmental Panel on Climate Change (IPCC), global mean temperature would rise between 0.9 and $3.5^{\circ} \mathrm{C}$ by the year 2100 [3], resulted drought and floods always that acute foods production. An additional 40 to 170 million more people will be underfed in poor developing countries as a direct consequence of climate change [4]. Since a huge number of peoples will be undernourished, it should be given more attention to production of major crops e.g. cereals, vegetables and tubers. So, it is a little chance to cultivate fruit crops in poor developing countries, results in fruits production rate will go down more from the current level. Indeed, the great forecast is that extreme weather events such as heavy precipitation, heat waves, and rising sea levels will occur in many parts of the world during the 21 st century [5] with resulting floods, drought, and salinity as the most critical consequences. There are no more redundant water resources and arable lands to deploy in enlargement the already over-stretched ones in many parts of the world. This generational challenge of producing enough fruit crops for a rapidly growing population under extreme. Climate change has the potential to modify hosts physiology and resistance, as well as alter the stages and rates of development of pathogens [6]. The most likely impacts would be shifted in the geographical distribution of the host and pathogen, change in the physiology of host-pathogen interactions and change in crop losses. As under climate change, plants may potentially be unable to migrate or adapt as readily as environmental conditions change. But most pathogens have advantage over plants because of their shorter generation time and in many cases the ability to move readily through wind dispersal. Because of these characteristics, rate of evolution will be highest in pathogens compared with hosts [7].

The global population continues to rise results in land progressively uses for non-agricultural activities. Besides, due to change climate, areas of inferior land like drought and saline lands are increased. As a result, productive land resources shrink and worries of climate change only magnify the challenge of increasing fruits production to feed the expanding population [8]. The watermelon production is potential part of the fruits production worldwide, which is important for the human health care by supplying vitamins, minerals and fibers. By the climate changing, amplify the challenge for rising fruit production to feed the population for the next decays. The introduction of varied elite melon fruit varieties that are competent of producing more yield and will be critically important to achieving sustainable fruits production security. This is also must required the reorientation of the cultivation strategies of the resulting high yielding, well adapted, and less input in cultivation of melons.

Herein, breeding technologies with respect to conventional and molecular for watermelon are discussed. The discussed scientific and technological resources for watermelon here might be necessary for the further improvement of watermelon.

\section{Molecular Breeding for Watermelon}

Usually, molecular breeding of any plant requires some fundamental resources. Among them, most important are: genetic information, genetic transformation systems, and regeneration systems. The advanced researches on these fundamental resources for molecular breeding of watermelon are discussed.

\subsection{Genetic Information for Watermelon}

Genes, which are involved in different functions in watermelon, are summarized in Table 1. A large number of the ESTs identified from watermelon flesh, which are homologous to genes previously reported to be important in fruit growth and ripening in other plant species [9]. They reported that 1046 random cDNA clones sequenced produced 832 "EST-unigenes" where 578 ESTs ranges from 338 to 699 bases have significant homology to amino acid sequences from the GenBank non-redundant protein database and classified them based on the degree of similarity ( $E$-value) to the closest counterpart sequence found in other plant species, as shown in Fig. 1. From leaves of watermelon at vegetative stage, randomly selected cDNA clones were sequenced and 704 watermelon cDNA clones were identified, in which 399 clones $(56.7 \%)$ revealed a high degree of sequence similarity to genes from other organisms and involved ten categories gene functions [10]. Guo et al. [11] performed half Roche/454 GS-FLX run for each of the four watermelon fruit developmental stages (immature white, white-pink flesh, red flesh and over-ripe) and obtained 577,023 high quality ESTs with an average length of 302.8 bp where $54.9 \%$ of the unigenes showed significant similarities to known sequences in GenBank non-redundant (nr) protein database and around two-thirds of them matched proteins of cucumber, the most closely-related species with a sequenced genome. Wechter et al. [12] identified 832 EST-unigenes by high-density photolithography arrays from watermelon at three distinct time-points in watermelon fruit development. Of 335 ESTs, 211 are significantly homology with known gene products and 96 had no significant matches with any database accession. Some functional genes are described below. 
Table 1. Summary of genes identified in watermelon related to different functions.

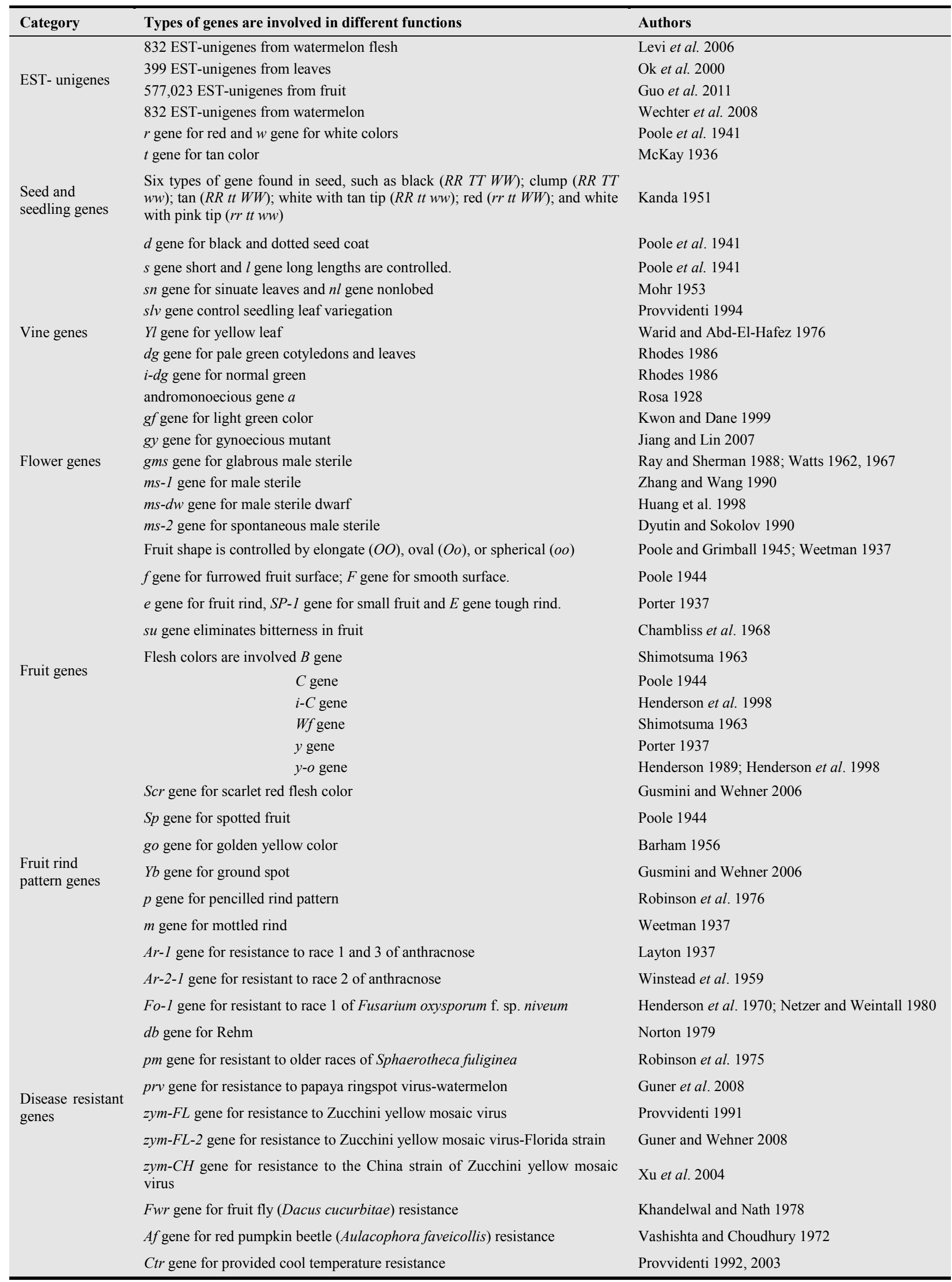




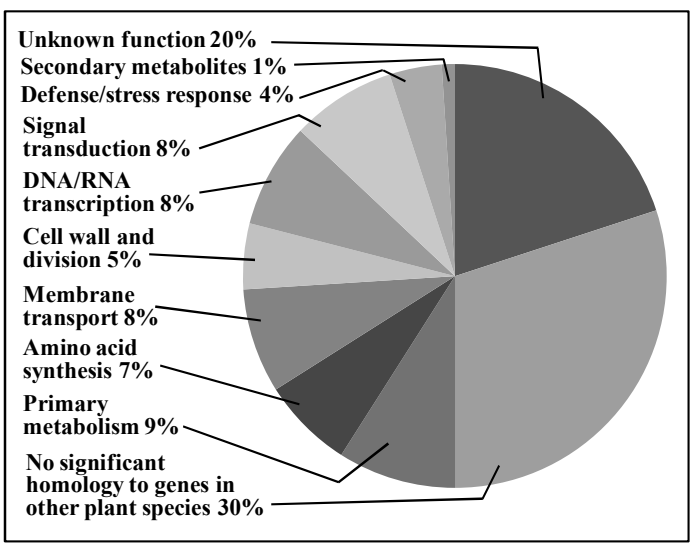

Figure 1. Distribution of ESTs according to their functions in watermelon fruit flesh [9].

Several genes like as sinuate leaves $(s n)$ and nonlobed $(n l)$ control leaf or foliage traits of watermelon [17]. Seedling leaf variegation which is resembled virus infection is controlled with $s l v$ [18]. It is linked or pleiotropic with Ctr for cool temperature resistance. Besides, leaf color genes such as, for yellow leaf, $Y l$ gene; green leaves, incompletely dominant $Y l$ gene [19]; pale green cotyledons and leaves $d g$ [20] normal green, $i-d g$ [20]. The juvenile albino ja [21] gene causes reduced chlorophyll in seedling tissues. The dominant gene $S p$ [22] causes round yellow spots to form on cotyledons, leaves and fruit. So far, four dwarf genes of watermelon have been identified that affect stem length and plant habit: $d w-1[23,24]$ and $d w-1 s$ [25] are allelic, and $d w-1, d w-2$ [26], and $d w-3$ [27] are non-allelic. The gene $t l$ results in tendrilless branches after the 5 th or 6 th node [28, 29].

The andromonoecious gene $a$ [30] controls monoecious $(A A)$ vs. andromonoecious (aa) sex expression in watermelon. Light green flower color is controlled by the single recessive gene, $g f$ [31]. A gynoecious mutant was discovered in 1996, and is controlled by a single recessive gene, gy [32]. Four genes for male sterility have been reported: Glabrous male sterile (gms) [33-35], male sterile $m s-1$ [36], male sterile dwarf ( $m s-d w)$ [27] and spontaneous male sterile $(m s-2)$ [37].

Fruit shape is controlled by a single, incompletely dominant gene, resulting in fruit that are elongate $(O O)$, oval $(O o)$, or spherical $(o o)[38,39]$. A single gene controls furrowed fruit surface $f$ [22] that is recessive to smooth $(F)$. Explosive rind (e) causes the fruit rind to burst or split when cut [40], and has been used to make fruit easily crushed by harvest crews for pollinator cultivars such as $S P-1$ that have small fruit not intended for harvest. Tough rind $(E)$ is an important fruit trait to give cultivars shipping ability. Rind toughness appears to be independent of rind thickness. A single recessive gene $s u$ [41] eliminates bitterness in fruit. Watermelon flesh color is controlled by several genes to produce scarlet red, coral red, orange, salmon yellow, canary yellow, or white. Genes conditioning flesh colors are $B$ [42], $C$ [22], $i-C$ [43], $W f$ [42], $y$ [40] and $y$-o [43, 44]. A single dominant gene, Scr, produces the scarlet red flesh color [45]. The gene $S p$ produces spotted fruit, making interesting effects as found in cultivars such as 'Moon and Stars' [22]. Golden yellow was inherited as a single recessive gene go [46] derived from 'Royal Golden' watermelon. The yellow belly, or ground spot, on 'Black Diamond Yellow Belly' is controlled by a single dominant gene, $Y b$. The recessive genotype, 'Black Diamond' has a ground spot that is white [45]. Weetman [39] proposed that three alleles at a single locus determined rind pattern. The allelic series was renamed to $G, g s$, and $g$ by Poole [22], since $g$ was used to name the recessive trait 'green', rather than $D$ for the dominant trait 'dark green'. The $g-s$ gene produces a striped rind. The watermelon gene $p$ for pencilled rind pattern has been reported in the gene lists since 1976 [47]. The $m$ gene for mottled rind was first described by Weetman in 'Long Iowa Belle' and 'Round Iowa Belle' [39].

There are 3 major genes control seed coat colors such as, red $(r)$, white $(w)$ [13], and $\tan (t)$ [14]. By the interaction of genes, it is produce six phenotypes: black $(R R T T W W)$; clump (RR TT ww); $\tan (R R t t W W)$; white with tan tip (RR tt $w w)$; red ( $r r t t W W)$; and white with pink tip ( $r r t t w w)$ [15]. A fourth gene, $d$ was suggested by [13] as a modifier, producing a black, dotted seed coat when dominant for $r, t$, and $\mathrm{w}$, but having no effect on other seed coat color genotypes. These four genes do not account for the green seed coat color found in some wild accessions. The seed lengths control short $(s)$ and long $(l)$ genes, with $s$ epistatic to $l$ [13]. The genotype $L L S S$ gives medium size, $l l S S$ gives long, and $L L s s$ or $l l s s$ gives short seeds. The Ti gene was non-allelic to the $s$ and $l$ genes which for tiny seed, was reported by Tanaka et al. [16]. Tiny seed from 'Sweet Princess' was dominant over medium-size seed and was controlled by a single dominant gene.

Resistance to race 1 and 3 of anthracnose (Colletotrichum lagenarium, formerly Glomerella cingulata var. orbiculare) is controlled by a single dominant gene $A r-1$ [48]. Resistance to race 2 of anthracnose is also controlled by a single dominant gene $A r-2-1$ [49]. Resistance to race 1 of Fusarium oxysporum f. sp. niveum is controlled by a single dominant gene Fo-1 [50, 51]. Gummy stem blight, caused by Didymella bryoniae (Auersw.) Rehm is inherited by a recessive gene $d b$ [52]. Watermelons were resistant to older races of Sphaerotheca fuliginea present in the U.S. in the 1970s, but a single recessive gene pm [53] for high susceptibility to powdery mildew was found in the plant introduction, PI 269677. Resistance to Papaya ringspot virus-watermelon strain was reported in accessions PI 244017, PI 244019 and PI 485583. It was controlled by a single recessive gene, prv [54]. A moderate level of resistance to Zucchini yellow mosaic virus was found in four landraces of Citrullus lanatus, but was specific to the Florida strain of the virus. Resistance was conferred by a single recessive gene $z y m-F L$ [55]. A high level of resistance to Zucchini yellow mosaic virus-Florida strain was found in PI 595203 that was controlled by a single recessive gene, 
zym-FL-2 [56]. Resistance to the China strain of Zucchini yellow mosaic virus was reported in PI 595203, controlled by a single recessive gene $z y m-\mathrm{CH}$ [57]. Genes for insect resistance have been reported in watermelon. Fruit fly (Dacus cucurbitae) resistance was controlled by a single dominant gene Fwr [58], and red pumpkin beetle (Aulacophora faveicollis) resistance was controlled by a single dominant gene $A f$ [59]. Stress resistance has been found in watermelon. The single dominant gene Ctr provided cool temperature resistance $[60,61]$.

\subsection{Genetic Transformation Systems for Watermelon}

Insertion of bacterial, fungal and virus resistance genes through recombinant DNA technology would facilitate the development of new disease resistant genotypes without significantly altering the genetic composition and desirable phenotypic qualities of accepted cultivars with high fruit quality. There are many stable genetic transformation has been reported for watermelon. Recovery of transgenic watermelon shoots and plantlets in vitro during transformation has generally been by use of the reporter GUS and nptII genes for selection in media containing kanamycin [62 - 65]. Delivery of recombinant DNA using biolistic methods poses an alternative to Agrobacterium-mediated transformation. Compton et al. [66] described parameters for optimizing transient expression of GUS in cotyledons following particle bombardment using a particle inflow gun (PIG). While optimum transient expression of GUS was reported, stable integration of recombinant DNA using this method was not obtained. The best method of genetically engineering watermelon may involve a combination of biolistics and Agrobacterium-mediated transformation. Compton et al. [67] observed that transient expression of GUS was improved when cotyledons were wounded with $1.1 \mu \mathrm{m}$ tungsten particles delivered using a PIG immediately before their inoculation with Agrobacterium. However, stable integration of recombinant DNA and regeneration of transgenic plants was not reported.

The traits in greatest demand at the current time are those of resistance to watermelon fruit blotch and the three main watermelon viruses. Watermelon fruit blotch is a devastating disease caused by Acidovorax avenae subsp. Citrulli [68]. Introduction and expression of cecropin encoding genes in transgenic watermelon plants may offer a path of resistance to watermelon fruit blotch. Cecropin is an insect protein that has antibacterial activity [69]. Resistance of watermelon to Zucchini yellows mosaic virus (ZYMV) has been identified in several wild genotypes [55, 70]. Unfortunately, fruit of these plants exhibit poor quality, requiring many years of crosses and selection to select hybrid cultivars with high level virus resistance and exceptional fruit quality. Expressions of transgenes that confer resistance to these viruses offer the hope of high-level virus resistance without altering fruit quality of existing cultivars. Researchers at Seminis Vegetable Seeds, Inc. (Saticov, CA) modified the protocol developed by Choi et al.
[62] to produce virus resistant transgenic watermelon plants expressing the coat protein genes of ZYMV and Watermelon mosaic virus (WMV) under control of the cauliflower mosaic virus $35 \mathrm{~S}$ promoter [63]. Transgenic watermelon plants against Fusarium wilt has been generated via pollen-tube pathway [71]. Transgenic watermelon rootstock resistant to Cucumber green mottle mosaic virus (CGMMV) has been developed using a cDNA encoding the CGMMV coat protein gene $(C G M M V-C P)$, and successfully transformed a watermelon rootstock named 'gongdae' [72]. To develop a transgenic watermelon resistant to multiple virus infection, a single chimeric transgene comprising a silencer DNA from the partial $N$ gene of Watermelon silver mottle virus (WSMoV) fused to the partial coat protein $(C P)$ gene sequences of Cucumber mosaic virus (CMV), CGMMV and WMV was constructed and transformed into watermelon via Agrobacterium-mediated transformation [73]. Through Agrobacterium-mediated transformation, the bar gene (Cho et al. 2008) have been expressed in transgenic watermelon. Also, transgenic watermelon plants expressing the HAL1 gene of Saccharomyces cerevisiae are able to increase salt tolerance [74]. Agrobacterium rhizogenes-mediated transgenic hairy roots were efficiently induced and selected from the hypocotyls of watermelon plant [75]. Transgenic watermelon lines have been developed by several commercial companies and field-tested a number of times, predominantly in USA, and also in Europe. Data on field tests of transgenic crops are available [76].

\subsection{Plant Regeneration Systems for Watermelon}

Among three fundamental resources for the molecular breeding, the in vitro plant regeneration systems are one of them. The plant regeneration systems in vitro for watermelon have been reported for the several times. The use of shoot tip explants has a potential application for the propagation of elite triploid cultivars and tetraploid watermelon breeding lines production. Many attempts have been made to adapt tissue culture procedures for the propagation of triploid genotypes [77]. Ahad et al.[78] reported that establishment of an efficient protocol for plant regeneration from its immature and mature embryo axis explants of diploid watermelon. We [79] reported a system for axillary shoots and plantlets regeneration from nodal segment of diploid watermelon through micropropagation (Fig. 2). The plant regeneration through adventitious shoots organogenesis has been reported from a wide range of diploid and tetraploid watermelon cultivars [80]. As the best source of explants, cotyledon of in vitro-germinated seedlings were reported in published works. Two- to five-day-old seedlings with their cotyledons in close contact have displayed the greatest organogenic competence [80]. Our research group [81] reported that leaf-derived callus showed an excellent performance for shoot regeneration through adventitious organogenesis from leaf-derived callus of diploid watermelon, as shown in Fig. 3. Somatic embryogenesis method is a practicable for plant propagation 
and a resource of genetic transformation. A limited study has been studied on somatic embryogenesis of watermelon [82]. Pro-embryos formation in the cell suspension culture from leaf-derived callus has been reported in diploid watermelon [83]. An efficient tissue culture technique can also increase the transformation efficiency, therefore, a reproducible and effective in vitro system for plant regeneration is crucial for the transgenic technology based genetic improvement of watermelon.

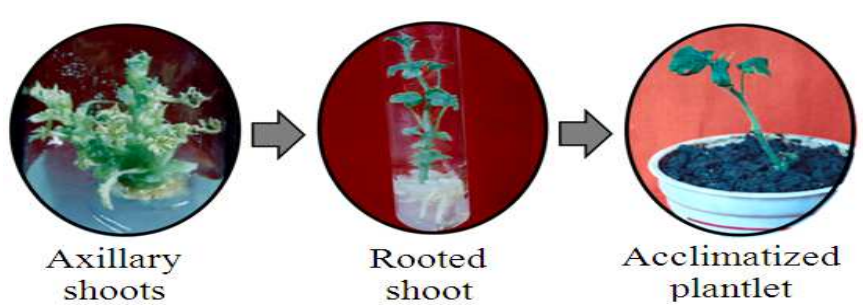

Figure 2. Axillary shoots and plant regeneration from a nodal segment of diploid watermelon through micropropagation.

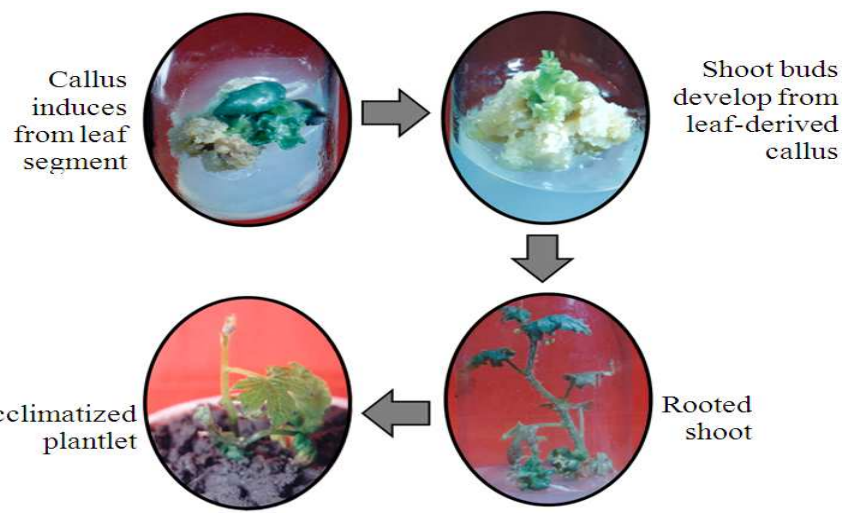

Figure 3. Adventitious shoots and plant regeneration from a leaf segment-derived callus of diploid watermelon through organogenesis.

\section{Disserted Improvement in Watermelon for Next Decays}

A genetically diverse portfolio of improved agronomic plant varieties, suited to a range of agroecosystems and farming practices, and resilient to climate change is key to sustainable production intensification [84]. The new elite varieties of watermelon predicted to address the bourgeoning drivers for production insecurity must be adapted to extreme weather conditions and the attendant continually evolving new strains and biotypes of pests and diseases. Extreme and changing patterns of drought and salinity are probably the most critical consequences of climate change and variations for which plant breeding of melons must develop well-adapted varieties. Additionally, the 21 st century plant breeding must cater to different prevailing farming systems and conditions - including rain-fed agriculture that accounts for a significant proportion of global melon production in places where erratic rainfall patterns are expected. The new elite varieties of melons must make more efficient use of inputs, and have improved nutritional qualities that meet the myriad dietary preferences of an increasingly more affluent, health-conscious, and generally more discerning consumer. Breeding objectives and strategies for melons must also lead to these crop varieties that fit into ecosystem-based approaches such as conservation agriculture that emphasizes zero tillage. The breeding of melon varieties which nutrients are severally suited for use as good feed, will contribute to assuaging the effects of the ever increasing competing demands from foodstuff.

\section{Future Techniques for Improvement of Watermelon}

Nowadays, the transgenic technology, especially recombinant technique for plant improvement is a very efficient field for improvement of plants but it could be changed with demand by breeders. Form the beginning, the genetic improvement techniques in plant are changing. The status of rising technologies is stated by Lusser et al. [85] in response to a request by the European Commission 'to provide information on the state of adoption and possible economic impact of new plant breeding techniques'. Lusser et al. [85] identified eight new such techniques and concluded that the new varieties ensuing from these techniques might be released within a few years. These new techniques and their features are: i) Zinc finger nuclease (ZFN), ii) Oligonucleotide directed mutagenesis (ODM), iii) Cisgenesis and intragenesis, iv) RNA-dependent DNA methylation (RdDM), v) Grafting (on GM rootstock), vi) Reverse breeding, vii) Agro-infiltration, viii) Synthetic 
genomics. Among new techniques, ODM, cisgenesis/intragenesis, and agro-infiltration were the most commonly used for developing crops and reached them at commercial development phase [85]. However, above advanced techniques all might be impact positively in the melon improvement. Although some techniques among them begin utilized in the crops improvement, the utilization of such methods is not attended in case of watermelon improvement. The worsening threats to global watermelon production security might be possible to rescue with application of advanced breeding techniques.

\section{Conclusions}

As fruits production, watermelon is top most level by weight worldwide. In fruits including apple, strawberry, orange, grape, etc, the advanced technologies are applied very much for their improvement. Therefore, it is more urgent now to improve melon fruits production due to its yield at the highest level. Using classical selection breeding system, watermelon has improved by a few characteristics, especially with seedless or low seeded watermelon production that released to farmers. Using breeding based on the transgenic technology, no variety or cultivar for watermelon is released to growers although many researches has been carried out as well as reported, especially on disease resistant traits. All transgenic lines of watermelon are till now under the field trail condition. Although the advanced transgenic breeding system has applied to improve many fruit plants, it is in infant stages for watermelon, owing to fundamental resources are not so well established. The global population rises continuously, results in agricultural land reduces progressively, and by changing climate, increasing drought and saline lands, which magnify the challenge of increasing fruits production to feed the expanding population. An increasing in the production of melons is required for a growing population over the next decades. In this paper, we described the current status of resources of molecular breeding that would be the necessary for improving watermelon.

\section{References}

[1] Compton ME, Gray DJ, and Gaba VP (2004) Use of tissue culture and biotechnology for the genetic improvement of watermelon. Plant Cell, Tiss. Org. Cult., 77 :231-243.

[2] FAOSTAT (2011) FAO statistical databases data sets. Available at $h$ ttp://faostat.fao.org/.

[3] Chakraborty S, Tiedemann AV and Teng PS (2000) Climate change: potential impact on plant diseases. Environ. Pollution, 108: 317-326.

[4] Evans A (2009) The Feeding of the Nine Billion: Global Food Security for the 21st Century. London: Chatham House.

[5] Intergovernmental Panel on Climate Change (IPCC) (2012) Summary for Policymakers. In: Managing the Risks of Extreme Events and Disasters to Advance Climate Change
Adaptation, CB Field, V Barros, TF Stocker, D Qin, DJ Dokken, KL Ebi, MD Mastrandrea, KJ Mach, G-K Plattner, SK Allen, M Tignor, and PM Midgley (eds.). Cambridge, Cambridge University Press. pp. 17-29.

[6] Prestidge RA and Pottinger RP (1990) The Impact of Climate Change on Pests, Diseases, Weeds and Beneficial Organisms Present in New Zealand Agricultural and Horticultural Systems. MAF Technology, Ruakura Agricultural Centre, Hamilton, NZ.

[7] Sutherst RW, Yonow T, Chakraborty S, O'Donnell C and White N (1996) A Generic Approach to Dening Impacts of Climate Change on Pests, Weeds and Diseases in Australasia. In: Greenhouse, Coping with Climate Change, WJ Bouma, GI Pearman, and MR Manning (Eds.). CSIRO, Australia, pp. 281-307.

[8] Secretariat of the Pacific Regional Environment Programme (SPREP) (2009) Climate Change, Variability and Sea- Level Change. Available http://www.sprep.org/topic/climate.htm.

[9] Levi A, Davis A, Hernandez A, Wechter P, Thimmapuram J, Trebitsh T, Tadmor Y, Katzir N, Portnoy V and King S (2006) Genes expressed during the development and ripening of watermelon fruit. Plant Cell Rep., 25: 1233-1245.

[10] Ok S, Chung YS, Um BY, Park MS, Bae J-M, Lee SJ and Shin JS (2000) Identification of expressed sequence tags of watermelon (Citrulus lanatus) leaf at the vegetative stage. Plant Cell Rep., 19: 932-937.

[11] Guo S, Liu J, Zheng Y, Huang M, Zhang H, Gong G, He H, Ren Y, Zhong S, Fei Z and Xu Y (2011) Characterization of transcriptome dynamics during watermelon fruit development: sequencing, assembly, annotation and gene expression profiles. BMC Genomics, 12: 454.

[12] Wechter WP, Levi A, Harris KR, Davis AR, Fei Z, Katzir N, Giovannoni JJ, Salman-Minkov A, Hernandez A, Thimmapuram J, Tadmor Y, Portnoy V and Trebitsh T (2008) Gene expression in developing watermelon fruit. Genomics, 9: 275 .

[13] Poole CF, Grimball PC and Porter DR (1941) Inheritance of seed characters in watermelon. J. Agr. Res., 63: 433-456.

[14] McKay FW (1936) Factor interaction in Citrullus. Seed coat color, fruit shape and markings show evidence of Mendelian inheritance in watermelon crosses. J. Hered., 27 :110-112.

[15] Kanda T (1951) The inheritance of seed-coat colouring in the watermelon. Jap. J. Genet., 7: 30-48.

[16] Tanaka T, Wimol S and Mizutani T (1995) Inheritance of fruit shape and seed size of watermelon. J. Jap. Soc. Hort. Sci., 64: 543-548.

[17] Mohr HC (1953) A mutant leaf form in watermelon. Proc. Assn. Southern Agr. Workers 50:129-130

[18] Provvidenti R (1994) Inheritance of a partial chlorophyll deficiency in watermelon activated by low temperatures at the seedling stage. HortSci., 29: 1062-1063.

[19] Warid A and Abd-El-Hafez AA (1976) Inheritance of marker genes of leaf color and ovary shape in watermelon, Citrullus vulgaris Schrad. The Libyan J. Sci., 6A: 1-8.

[20] Rhodes BB (1986) Genes affecting foliage color in 
watermelon. J. Hered ., 77: 134-135.

[21] Zhang XP, Rhodes BB and Bridges WC (1996b) Phenotype, inheritance and regulation of expression of a new virescent mutant in watermelon: juvenile albino. J. Amer. Soc. Hort. Sci., 121: 609-615.

[22] Poole CF (1944) Genetics of cultivated cucurbits. J. Hered., 35: $122-128$.

[23] Mohr HC (1956) Mode of inheritance of the bushy growth characteristics in watermelon. Proc. Assn. Southern Agr. Workers, 53: 174.

[24] Mohr HC and Sandhu MS (1975) Inheritance and morphological traits of a double recessive dwarf in watermelon, Citrullus lanatus (Thunb.) Mansf. J. Amer. Soc. Hort. Sci., 100: 135-137.

[25] Dyutin KE and Afanas'eva EA (1987) Inheritance of the short vine trait in watermelon. Cytology \& Genetics (Tsitologiya $i$ Genetika), 21: 71-73.

[26] Liu PBW and Loy JB (1972) Inheritance and morphology of two dwarf mutants in watermelon. J. Amer. Soc. Hort. Sci., 97: $745-748$.

[27] Huang H, Zhang X, Wei Z, Li Q and Li X (1998) Inheritance of male-sterility and dwarfism in watermelon [Citrullus lanatus (Thunb.) Matsum. and Nakai]. Scientia Horticulturae, 74: $175-181$

[28] Lin D, Wang T, Wang Y, Zhang X and Rhodes BB (1992) The effect of the branchless gene $b l$ on plant morphology in watermelon. Cucurbit Genet Coop Rep., 15: 74-75

[29] Rhodes BB, Zhang XP, Baird VB and Knapp H (1999) A tendrilless mutant in watermelon: phenotype and inheritance. Cucurbit Genetics Coop Rep., 22: 28-30.

[30] Rosa JT (1928) The inheritance of flower types in Cucumis and Citrullus. Hilgardia, 3: 233-250.

[31] Kwon YS and Dane F (1999) Inheritance of green flower color $(g f)$ in watermelon (Citrullus lanatus). Cucurbit Genet Coop Rep., 22: 31-33.

[32] Jiang XT and Lin DP (2007) Discovery of watermelon gynoecious gene, gy. Acta Hort. Sinica, 34: 141-142.

[33] Ray DT and Sherman JD (1988) Desynaptic chromosome behavior of the gms mutant in watermelon. J. Hered., 79: 397-399.

[34] Watts VM (1962) A marked male-sterile mutant in watermelon. Proc. Amer. Soc. Hort. Sci., 81: 498-505.

[35] Watts VM (1967) Development of disease resistance and seed production in watermelon stocks carrying the $m s g$ gene. Proc. Amer. Soc. Hort. Sci., 91: 579-583.

[36] Zhang XP and Wang M (1990) A genetic male-sterile (ms) watermelon from China. Cucurbit Genetics Coop Rep., 13. 45.

[37] Dyutin KE and Sokolov SD (1990) Spontaneous mutant of watermelon with male sterility. Cytology \& Genetics (Tsitologiya i Genetika), 24: 56-57.

[38] Poole CF and Grimball PC (1945) Interaction of sex, shape, and weight genes in watermelon. J. Agr. Res., 71: 533-552.
[39] Weetman LM (1937) Inheritance and correlation of shape, size, and color in the watermelon, Citrullus vulgaris Schrad. Iowa Agr. Expt. Sta. Res. Bul., 228: 222-256.

[40] Porter DR (1937) Inheritance of certain fruit and seed characters in watermelons. Hilgardia, 10: 489-509.

[41] Chambliss OL, Erickson HT and Jones CM (1968) Genetic control of bitterness in watermelon fruits. Proc. Amer. Soc. Hort. Sci., 93: 539-546.

[42] Shimotsuma M (1963) Cytogenetical studies in the genus Citrullus. VII. Inheritance of several characters in watermelons. Jap. J. Breeding, 13: 235-240.

[43] Henderson WR, Scott GH and Wehner TC (1998) Interaction of flesh color genes in watermelon. J. Hered., 89: 50-53.

[44] Henderson WR (1989) Inheritance of orange flesh color in watermelon. Cucurbit Genet Coop Rep., 12: 59-63.

[45] Gusmini G and Wehner TC (2006) Qualitative inheritance of rind pattern and flesh color in watermelon. J. Hered., 97: 177-185.

[46] Barham WS (1956) A study of the Royal Golden watermelon with emphasis on the inheritance of the chlorotic condition characteristic of this variety. Proc. Amer. Soc. Hort. Sci., 67: 487-489.

[47] Robinson RW, Munger HM, Whitaker TW and Bohn GW (1976) Genes of the Cucurbitaceae. HortSci., 11: 554-568.

[48] Layton DV (1937) The parasitism of Colletotrichum lagenarium (Pass.) Ells. and Halst. Iowa Agr. Expt. Sta. Ann. Bul., 223.

[49] Winstead NN, Goode MJ and Barham WS (1959) Resistance in watermelon to Colletotrichum lagenarium races 1, 2, and 3 . Plant Dis. Rep., 43: 570-577.

[50] Henderson WR, Jenkins SF Jr and Rawlings JO (1970) The inheritance of Fusarium wilt resistance in watermelon, Citrullus lanatus (Thunb.) Mansf. J. Amer. Soc. Hort. Sci., 95 276- 282.

[51] Netzer D and Weintall C (1980) Inheritance of resistance to race 1 of Fusarium oxysporum f. sp. niveum. Plant Dis., 64: 863-854.

[52] Norton JD (1979) Inheritance of resistance to gummy stem blight in watermelon. HortSci., 14: 630-632.

[53] Robinson RW, Provvidenti R and Shail JW (1975) Inheritance of susceptibility to powdery mildew in the watermelon. J. Hered., 66: 310-311.

[54] Guner N, PesicVan-Esbroeck Z and Wehner TC (2008) Inheritance of resistance to Papaya ringspot virus-watermelon strain in watermelon. J. Hered., 90: 107-115.

[55] Provvidenti R (1991) Inheritance of resistance to the Florida strain of zucchini yellow mosaic virus in watermelon. HortSci., 26: 407-408.

[56] Guner N, Wehner TC (2008) Inheritance of resistance to Zucchini yellow mosaic virus in watermelon. J. Hered., 71: 77-85.

[57] Xu Y, Kang D, Shi Z, Shen H and Wehner TC (2004) Inheritance of resistance to zucchini yellow mosaic virus and 
watermelon mosaic virus in watermelon. J. Hered., 96: 498-502.

[58] Khandelwal RC and Nath P (1978) Inheritance of resistance to fruit fly in watermelon. Can. J. Genet. Cytol., 20: 31-34.

[59] Vashishta RN and Choudhury B (1972) Inheritance of resistance to red pumpkin beetle in muskmelon, bottle gourd and watermelon. Proc. 3rd Intl. Symposium Sub-Trop. Hort., 1: $75-81$.

[60] Provvidenti R (1992) Cold resistance in accessions of watermelon from Zimbabwe. Cucurbit Genet Coop Rep., 15: 67-68.

[61] Provvidenti R (2003) Naming the gene conferring resistance to cool temperatures in watermelon. Cucurbit Genet Coop Rep., 26: 31 .

[62] Choi PS, Soh WY, Kim YS, Yoo OJ and Liu JR (1994) Genetic transformation and plant regeneration of watermelon using Agrobacterium tumefaciens. Plant Cell Rep., 13: 344-348.

[63] Tricoli DM, Carney KJ, Russell PF, Quemada HD, McMaster RJ, Reynolds JF and Deng RZ (2002) Transgenic plants expressing DNA constructs containing a plurality of genes to impart virus resistance. United States Patent No. $6,337,431$.

[64] Akashi K, Morikawa K and Yokota A (2005) Agrobacterium-mediated transformation system for the drought and excess light stress-tolerant wild watermelon (Citrullus lanatus). Plant Biotechnol., 22(1): 13-18.

[65] Reed J, Privalle L, Powell ML, Meghji M, Dawson J, Dunder E, Suttie J, Wenck A, Launis K, Kramer C, Chang YF, Hansen G, Wright M and Chang YF (2001) Phosphomannose isomerase: an efficient selectable marker for plant transformation. In Vitro Cell. Dev. Biol. Plant, 37: 127-132.

[66] Compton ME, Gray DJ, Hiebert E and Lin CM (1993) Expression of the $\beta$-glucuronidase gene in watermelon cotyledon explants following particle bombardment or infection with Agrobacterium tumefaciens. HortSci., 28: 138 .

[67] Compton ME, Gray DJ, Hiebert E and Lin CM (1994) Microprojectile bombardment prior to co-cultivation with Agrobacterium improves GUS expression in watermelon cotyledons. In Vitro Cell. Dev. Biol., 30A: 62.

[68] Rane KK and Latin RX (1992) Bacterial fruit blotch of watermelon: association of the pathogen with seed. Plant Dis., 76: 509-512.

[69] Jaynes JM, Xanthopoulos KG, Destefano-Beltran L and Dodds JH (1987) Increasing bacterial disease resistance in plants utilizing antibacterial genes from insects. Bio-Essays., 6: $263-270$

[70] Boyhan GJ, Gudauskas RT, Norton JD and Abrahams BR (1994) Evaluation of watermelon and related germplasm for resistance to the Egyptian strain of zucchini yellow mosaic virus. Plant Dis., 78: 100.

[71] Chen WS, Chiu CC, Liu HY, Lee TL, Cheng JT, Lin CC, Wu YJ and Chang HY (1998) Gene transfer via pollen-tube pathway for anti-fusarium wilt in watermelon. Biochem. Mol. Biol. Int., 46: 1201-1209.
[72] Park SM, Lee JS, Jenal S, Jeon SL, Shin YS, Her NH, Lee JH, Lee M, Ryu KH, Yang SG and Harn CH (2005) Transgenic watermelon rootstock resistant to CGMMV (Cucumber green mottle mosaic virus) infection. Plant Cell Rep., 24 : 350-356.

[73] Lin C-Y, Ku H-M, Chiang Y-H, Ho H-Y, Yu T-A and Jan F-J (2012) Development of transgenic watermelon resistant to Cucumber mosaic virus and Watermelon mosaic virus by using a single chimeric transgene construct. Transgenic Res., 21: 983-993.

[74] Ellul P, Rios G, Atare A, Roig LA, Serrano R and Moreno V (2003) The expression of Saccharomyces cerevisiae HAL1 gene increases salt tolerance in transgenic watermelon [Citrullus lanatus (Thunb.) Matsum. \& Nakai.]. Theor. Appl. Genet., 107: 462-469.

[75] Kajikawa, M., Morikawa, K., Abe, Y., Yokota, A., and Akashi, K. (2010). Establishment of a transgenic hairy root system in wild and domesticated watermelon (Citrullus lanatus) for studying root vigor under drought. Plant Cell Rep., 29: 771-778.

[76] Anonymous M (2002). Information Systems for Biotechnology. Available at http://www.isb.vt.edu/cfdocs/fieldtestsl.cfm.

[77] Adelberg J and Rhodes BB (1989) Micropropagation from zygotic tissues of watermelon. Proc. Cucurbitaceae USDA/ARS, 89: 110-112.

[78] Ahad A, Islam R, Hossian M, Khalekuzzaman M and Joarder OI (1994) Plant regeneration from immature and mature embryo axes of watermelon. Plant Tissue Cult., 2: 39-44.

[79] Sultana RS and Bari MA (2003) Effect of different plant growth regulators on direct regeneration of watermelon (Citrullus lanatus Thumb.). Plant Tissue Cult., 13(2): 173-177.

[80] Compton ME and Gray DJ (1993) Shoot organogenesis and plant regeneration from cotyledons of diploid, triploid and tetraploid watermelon. J. Am. Soc. Hort. Sci., 118: 151-157.

[81] Sultana RS, Bari MA, Rahman MH, Rahman MM, Siddique NA and Khatun N (2004) In vitro regeneration of plantlets from leaf explant of watermelon (Citrullus lanatus Thunb.). Biotech., 3: 131-135.

[82] Kahar LK, Karande SS and Belhekar BM (2009) Study of biochemical mechanism of embryogenesis in watermelon by using molecular marker. Intl. J. Plant Sci., 4(1) :333-337.

[83] Sultana RS and Rahman MM (2012) Ontogeny of embryogenic aggregates in suspension culture of diploid watermelon [Citrullus lanatus (Thunb.)]. Intl. J. Agron. Agri. Res., 2: 40-46.

[84] Food and Agriculture Organization of the United Nations (FAO) (2011) Save and grow - a policy maker's guide to the sustainable intensification of smallholder crop production. Rome.

[85] Lusser M. Parisi C. Plan D and Rodríguez-Cerezo E (2011) New Plant Breeding Techniques. In: State-of-the-art and Prospects for Commercial Development, M Lusser, C Parisi, D Plan, E Rodríguez-Cerezo (eds.). Luxembourg, Publications Office of the European Union. pp. 104-110. 